\title{
進行腎細胞癌の治療成績
}

-17 年間の変遷一

\begin{tabular}{|c|c|c|c|c|}
\hline 東京大学 & 新 & 铝科 & 阿曽住 & 双） \\
\hline 本間 & 之夫 & 佐々木幸弘 & 押 & 正也 \\
\hline 簑和田 & 滋* & 英二 & 阿曽 & 佳郎 \\
\hline
\end{tabular}

\section{CLINICAL OBSERVATIONS OF ADVANCED RENAL CELL CARCINOMAS} - The Chronological Change Between 1975 and 1991-

Yukio Homma, Yukihiro Sasaki, Masaya Oshi, Shigeru Minowada*, Eiji Higashihara and Yoshio Aso

Department of Urology, Faculty of Medicine, The University of Tokyo

(Director: Prof. Y. Aso)

Nobuo Moriyama and Atsushi Tajima

Department of Urology, Branch Hospital, Faculty of Medicine, The University of Tokyo

(Director: Associate Prof. A. Tajima)

*Tokyo Teishin Hospital

An analysis has been undertaken to determine chronological changes that have occurred in the clinical features and treatments of advanced renal cell carcinomas. To accomplish this, 96 renal cell carcinoma cases, handled by the authors' department and at the branch hospital, were divided into two groups: 48 patients treated between 1975 and 1983 (group 1) and 48 patients treated between 1984 and 1991 (group 2).

Between the two groups, no differences were seen in the sex ratio, the mean age, and the ratio of those who were found to be advanced cases at the time of diagnosis and those whose cancers had advanced after undergoing a nephrectomy. Concerning treatment, interferon (IFN) and UFT were more frequently used in treating group 2 than group 1, and chemothrapy, radiotherapy, and endocrine therapy less frequently used. No differences were seen in the prognosis between the two groups; however, in those who had advanced after nephrectomy, group 2 cases survived for a significantly longer period than did group 1 cases. Patients who survived for 5 years or longer accounted for two cases in group 1 and 5 cases in group 2 and combination therapies involving surgery, IFN, UFT, or similar medications were used for their treatments.

These results suggest that adjuvant therapies, such as surgery, IFN, and UFT, have possibly contributed to prolonging survival, especially for cases that advanced after nephrectomy.

Key words: renal cell carcinoma, advanced cancer, treatment

要旨：進行腎細胞癌の臨床的特徵の経時代的変化を明らかにするため, 1975年から1991年までの17年間 に経験した94例を前期（48例）と後期（46例）に分けて比較検討した。その病型は，遠隔転移を有する 症例が80例 (85.1\%) と大部分を占めた。症例の男女比, 年齢, 診断時に既に進行癌であったもの（診 断時進行癌）と腎摘後に進行癌になったもの（腎摘後進行癌）の割合も同様で, 前期と後期での病像に

* 現 東京逓信病院泌尿器科 
大きな差はなかった。治療法では後期で interferon (IFN)やUFT が頻用されるようになり，逆にその 他の抗癌剂, 放射線療法, 内分泌療法の使用頻度は低下していた。前期之後期の生存率の比較では全体 の予後の差を認めなかった。しかし腎摘後進行癌においては後期は前期に比して有意に予後は良好で, この現象は診断時進行癌には見られなかった。 また 5 年以上の長期生存例は前期に 2 例, 後期に 5 例あ り,これらはいずれも外科的切除, IFN, UFTなどの併用療法を受けていた。 以上の結果より, 進行腎 癌は前期之後期ではその病像や予後に明らかな変化は認められないものの, 外科的手術, IFN, UFT な ぞの集学的治療が治療成績の向上に寄与することが示唆された。

キーワード：腎細胞癌, 進行癌, 治療成績

\section{緒言}

腎細胞癌の診断と治療は近年変化してきた。診断で はCT や超音波の画像診断機器のめざましい発達が あった ${ }^{1)}$ ここれにより診断能の向上が計られたばかり でなく，偶然に発見される腎細胞癌の数も急増し だ23)。また，治療においては interferon(IFN)をはじ めとする種々の biological response modifier (BRM) が導入されてきた ${ }^{4)}$ ここれらの変化は治療成績の向上 にも何らかの寄与をしていることが期待される.

しかしこのような変化に反して, 進行期にある腎細 胞癌の治療成績は依然不良である ${ }^{5) 6}$. そこで今回の研 究では, 特に進行腎細胞癌について，1975年から1991 年の 17 年間に当科及び分院で経験した 94 例を前期と後 期に分け，その臨床像の経時的変遷について解析を 行った。

\section{対象と方法}

1975年から1991年の間に東京大学及び分院の泌尿器 科で経験した進行腎細胞癌を対象とした。なおこの間, 1977年 3 月までは高安久雄名誉教授が，1987年 3 月ま では新島端夫名誉教授が, 教室主任を務められた。

対象症例を以下の類型, 区分に従って分類し, 各々 の群でその臨床的特徵, 治療方法, 予後について検討 した。なお予後は原発巣発見ではなく進行癌と診断さ れた後の予後とし, 最終観察時点を1992年12月31日と した。

1）進行腎細胞癌の定義之類型

進行腎細胞癌を以下の類型に分類した。

1. 同側副腎を除く他臟器転移 (M1, N4)

2. リンパ節転移 $(\mathrm{N} 1 \sim 3)$

3. 下大静脈腫瘍血栓 (V2)

4. Gerota 筋膜外への直接浸潤 (T4)

5. 同時性両側性腎癌

2) 前期と後期の区分

前期と後期の区分は進行癌の診断時とし，17年間を ほぼ 2 分して，1975年から1983年までを前期，1984年
から1991年までを後期とした，従って，例えば前期に 腎摘して後期に転移が発見された例は後期進行癌とし た。

\section{3）進行癌の診断時による区分}

腎細胞癌の原発巣発見時にあわせて進行癌と診断さ れた症例を「診断時進行癌」とし, 腎摘後の経過中に 進行癌と診断されたものを「腎摘後進行癌」と分類し た。

\section{4）統計的解析}

生存率は Kaplan-Meier 法で算出し, 一般化 Wilcoxon 検定を行った. 症例数の分布については $\chi^{2}$ 検定 を, 平均值の比較についてはStudent's $\mathrm{t}$ 検定を用い た.

\section{結 果}

対象症例は全体で94例であった。 その背景を表 1 に 示した. 前期には48例, 後期には46例の症例があった. 男女比, 平均年齢については前後で差を認めなかった。 診断時進行癌々腎摘後進行癌の割合も変化はなかっ た。診断時進行癌で腎摘が行われた症例は，前期では 28例中16例 (57.1\%) に対し, 後期では31例中23例 (74.2\%)と増加がみられたが, 統計的には差はなかっ た.

表 2 に進行癌の類型別に症例数を示した.94例全体 では遠隔転移のみの症例が63例であり, 遠隔転移に加 えて他の条件を有するものは17例であった。従ってほ とんどの進行癌は遠隔転移を有していた。リンパ節転

表 1 対象症例の背景

\begin{tabular}{l|c|c|c}
\hline & $\begin{array}{c}\text { 前期 } \\
1975 \sim 1983\end{array}$ & $\begin{array}{c}\text { 後期 } \\
1984 \sim 1991\end{array}$ & 計 \\
\hline 症例数 & 48 & 46 & 94 \\
(男/莎) & $40 / 8$ & $38 / 8$ & $78 / 16$ \\
平均年龄 & 59.8 & 62.1 & 60.9 \\
診断時進行癌 & 28 & 31 & 59 \\
(腎摘無/有) & $(12 / 16)$ & $(8 / 23)$ & $(20 / 39)$ \\
腎摘後進行癌 & 20 & 15 & 35 \\
\hline
\end{tabular}


表 2 進行腎細胞癌の類型別症例数

\begin{tabular}{|c|c|c|c|c|c|}
\hline & \multicolumn{2}{|r|}{ 期 } & \multicolumn{2}{|c|}{ 後 期 } & \multirow{2}{*}{ 計 } \\
\hline & 診断時 & 腎摘後 & 診断時 & 腎摘後 & \\
\hline 遠隔転移のみ & 15 & 16 & 17 & 15 & 63 \\
\hline 遠隔転移＋他の条件 & 10 & 2 & 5 & 0 & 17 \\
\hline リソパ節転移 & 3 & 2 & 6 & 0 & 11 \\
\hline その他 & 0 & 0 & 3 & 0 & 3 \\
\hline 計 & 28 & 20 & 31 & 15 & 94 \\
\hline
\end{tabular}

進行腎細胞癌の条件は

1 同側副腎を除く他臓器転移 (M1, N4)

2 リンパ節転移 $(\mathrm{N} 1 \sim 3)$

3 下大静脈腫瘍血栓 (V2)

4 Gerota 筋膜外への直接浸潤 (T4)

5 同時性両側性腎癌

のいずれかを満たすものとした.

図 1 腎摘後進行癌における腎摘から進行腎細胞癌に なるまでの期間. 前期は $24.4 \pm 19.1$ 月で後期は $34.4 \pm 30.3$ 月で前期が短い傾向があった（ $\mathrm{p}<$ $0.1)$.

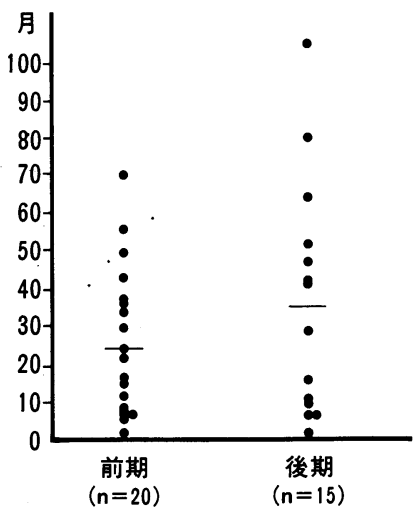

移のみの症例は全体で11例であった，その他の 3 例は 後期のみにみられ，下大静脈腫瘍血栓が 2 例, リンパ 節転移 + Gerote 筋膜外への直接漫潤の症例が 1 例で あった. しかし前期と後期では際立った類型別症例数 の違いは認められなかった。

図 1 は腎摘後進行癌で, 腎摘後から進行癌の診断ま

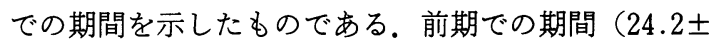

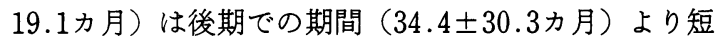
い傾向がみられた $(\mathrm{p}<0.1)$.

治療法の内容は表 3 に示した。同一症例に複数の治 療法を施行している場合は重複して記載した。また前 期に進行癌と診断された症例が後期でも治療を受けた 場合は, 後期の治療内容は後期の治療に加えた. BRM
表 3 進行腎細胞癌の治療法

\begin{tabular}{l|c|c}
\hline & 前 期 & 後 期 \\
\hline 外科的切除 & 9 & 9 \\
\hline BRM & 13 & 43 \\
IFN & 20 & 6 \\
PSK, Picibanil & 0 & 12 \\
IL-1, IL-2, TNF & 2 & 3 \\
その他 & & \\
\hline 化学療法剂 & 18 & 28 \\
5FU 系 & 23 & 7 \\
その他 & 15 & 6 \\
\hline 放射線 & & \\
\hline その他 & 13 & 1 \\
MPA & 3 & 1 \\
その他 & 48 & 46 \\
\hline \multicolumn{1}{c|}{ 計 } &
\end{tabular}

MPA : medroxyprogesterone acetate 併用治療は重複して記載。

表 4 進行腎細胞癌の予後

\begin{tabular}{|c|c|c|c|c|c|c|c|}
\hline \multicolumn{4}{|c|}{$\mathrm{A}$ ：全例 } & \multicolumn{4}{|c|}{ B：生存例, 他因死例 } \\
\hline \multicolumn{2}{|c|}{ 観察期間 } & 前期 & 後期 & \multicolumn{2}{|c|}{ 観察期間 } & 前期 & 後期 \\
\hline & $<1$ 年 & 20 & 17 & & $<1$ 年 & 2 & 3 \\
\hline 1 年 $\leqq$ & $<3$ 年 & 20 & 21 & 1 年 $\leqq$ & $<3$ 年 & 0 & 5 \\
\hline 3 年 & $<5$ 年 & 6 & 3 & 3 年 & $<5$ 年 & 0 & 2 \\
\hline 5 年 $\leqq$ & & 2 & 5 & 5 年 $\leqq$ & & 2 & 4 \\
\hline & & 48 & 46 & & & 4 & 14 \\
\hline
\end{tabular}

による治療では, IFN が13件から後期では43件に増加 していた，他の BRM では，前期には PSK, picibanil が多く用いられ，後期には IL-1, IL-2, TNFなどが多 用されていた。化学療法は, 5-fluorouracyl (5-FU) 系 の薬剤が多用され, 後期では更に使用頻度は上昇して いたが，その他の化学療法剤（主にMitomycin C, Doxorubicin, Bleomycin, Vincristine, Actinomycin D)はほとんど用いられなくなっていた，同様に放射線 治療や medroxyprogesterone acetate による治療も 明らかに使用頻度は低下していた。

予後については全例の観察期間を表 $4 \mathrm{~A}$ に, 生存例, 他因死例の観察期間を表 4B に示した。表 4A の通り 前期と後期では観察期間の大きな差を認めなかった。 しかし前期では48例中 4 例のみが生存または他因死 で, 残り44例は癌死したのに対し, 後期では癌死は46 例中32例にとどまった。 5 年以上観察可能であった例

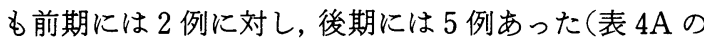


表 55 年以上生存例の治療内容

\begin{tabular}{|c|c|c|c|c|c|c|c|}
\hline \multirow{2}{*}{ 症例 } & \multirow{2}{*}{ 転移栄 } & & 治 & 療 & 内 & & \multirow{2}{*}{ 転 㷌 } \\
\hline & & \multicolumn{3}{|c|}{ 期 } & 後 & 期 & \\
\hline $1^{*}$ & 脳 & \multicolumn{3}{|c|}{ 外科的切除, 他の化療 } & \multicolumn{2}{|c|}{ - } & $\begin{array}{l}14 \text { 年 } 9 \text { 力月後 } \\
\text { 他因死 }\end{array}$ \\
\hline 2 & 肺 & $5 \mathrm{FU}$ 系, & 他の化療 & & \multicolumn{2}{|c|}{ IFN, TNF, UFT } & $\begin{array}{l}10 \text { 年 } 6 \text { 力月後 } \\
\text { 癌有生存中 }\end{array}$ \\
\hline $3^{*}$ & 肺 & \multicolumn{3}{|c|}{ - } & \multicolumn{2}{|c|}{ UFT, IL-2, IFN, 他の化療 } & $\begin{array}{l}5 \text { 年 } 7 \text { カ月後 } \\
\text { 癌死 }\end{array}$ \\
\hline $4^{*}$ & 骨 & \multicolumn{3}{|c|}{ - } & \multicolumn{2}{|c|}{ IFN, UFT, 外科的切除 } & $\begin{array}{l}5 \text { 年 } 5 \text { 力月後 } \\
\text { 癌有生存中 }\end{array}$ \\
\hline 5 & 肺 & \multicolumn{3}{|c|}{ - } & \multicolumn{2}{|c|}{ IFN, UFT, 外科的切除 } & $\begin{array}{l}6 \text { 年 } 2 \text { 力月後 } \\
\text { 癌無生存中 }\end{array}$ \\
\hline 6 & 肺 & \multicolumn{3}{|c|}{ - } & \multicolumn{2}{|l|}{ IFN } & $\begin{array}{c}7 \text { 年 } 9 \text { 力月後 } \\
\text { 癌有生存中 }\end{array}$ \\
\hline 7 & 肺 & \multicolumn{3}{|c|}{ - } & \multicolumn{2}{|c|}{ UFT, 外科的切除 } & $\begin{array}{c}6 \text { 年 } 7 \text { 力月後 } \\
\text { 癌無生存中 }\end{array}$ \\
\hline
\end{tabular}

* 診断時進行癌. 無印 腎摘後進行癌.

図 2 進行腎細胞癌の生存率一前期と後期全例の比較一

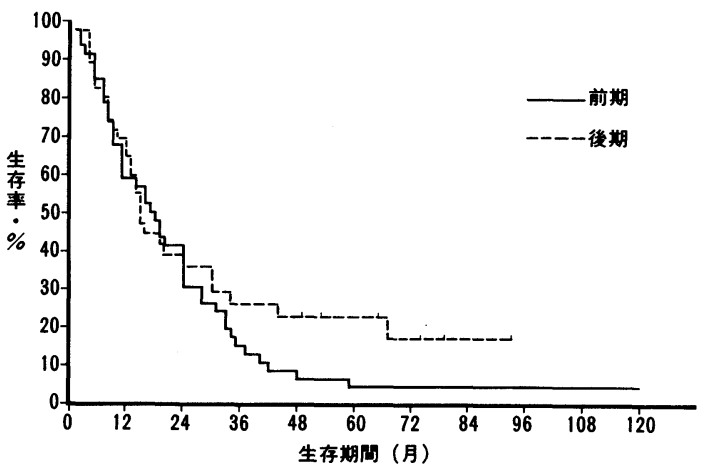

有意差なし（ $\mathrm{p}>0.1 ）$.
最下段).この 7 例の治療内容を表 5 に示した。長期生 存例では UFT や IFN に加之外科的切除も多く併用 されていた。

生存率は図 2 と図 3 に示した。全体では後期でやや 良好に見えるが有意差は認められなかった(図 2)。こ れを診断時進行癌（図 3A) と腎摘後進行癌 (図 3B) に分け，前期と後期の予後を比較すると，診断時進行 癌ではやはり差はなかった。しかし腎摘後進行癌では 前期に比べて後期で有意に生存率の改善が見られた $(\mathrm{p}<0.04)$.

\section{考察}

今回, 進行腎細胞癌の臨床像の時代的变化を1975年 から1983年までの前期と1984年から1991年までの後期 に分けて比較することで検討した。

図 3 診断時進行癌と腎摘後進行癌の生存率

$3 \mathrm{~A}$ 診断時進行癌.

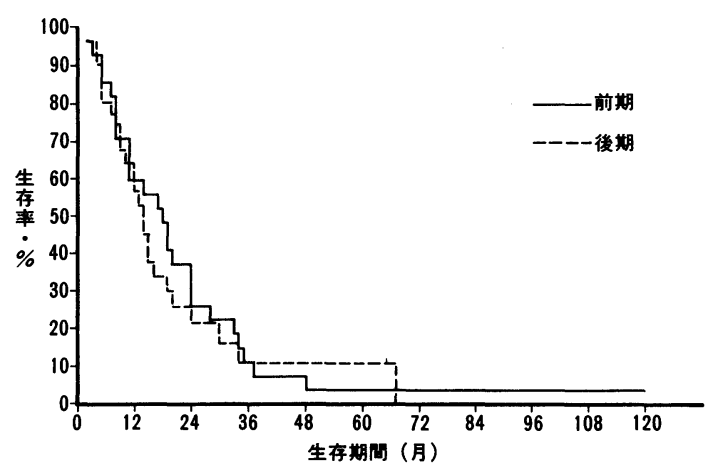

有意差なし $(p<0.1)$
3B 腎摘後進行癌

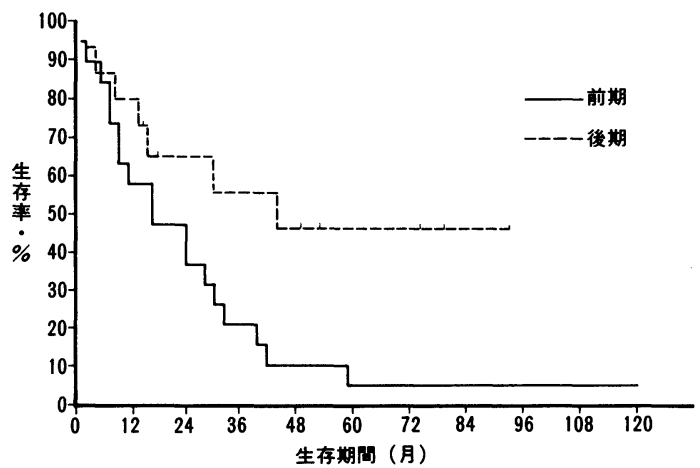

後期 $>$ 前期 $(p<0.04)$ 
近年腎細胞癌は偶発的に発見される症例が増えてき ており，全体の予後の改善につながっていると報告さ れている ${ }^{3)}$. しかし，診断時に既に進行癌である症例 は，前期と後期ともその症例数には差はなかった。す なわち早期発見例が増えている一方で，診断時に既に 進行癌である症例も依然として多いことが示された。 その類型でも遠隔転移を有する症例が80/94（85.7\%） とほとんどで，リンパ節転移のみあるいは局所の浸潤 のみの症例は少なく，前期と後期ではその病像に大き な違いはなかった。

進行腎細胞癌の治療については，最近は $\left(\mathrm{FN}^{7) 8}\right.$ や5 FU 系抗癌剂の ${ }^{9}$ 有効性を示す報告が多くみられる。一 方, 内分泌療法 ${ }^{10)}$ や放射線療法 ${ }^{1112)}$ は予後の改善には あまり有効ではないともされる。これらを反映して， 今回の検討でも後期では IFN p5FU 系の薬物が多用 されるようになった一方で，放射線，他の抗癌剂や内 分泌療法はあまり用いられなくなっていた。また肺転 移の外科的切除については，症例を限定して行えば有 効であるとされる ${ }^{13) 14)}$. 大脳転移にも外科的切除で根 治性が期待されるとの報告もある15)，更に現在ではこ らした種々の治療を総合した併用療法が試みられてき ている(1)16)，事実今回報告した内での長期生存例には 脳, 肺, 骨の外科的切除や IFN, UFT などの併用療法 を受けていた症例が汪とんどであった。

このように診断技術や治療法の進歩が期待されたに もかかわらず, 全体の生存率では前期と後期の全体で は差はなかった。しかし診断時進行癌と腎摘後進行癌 とに分けて前期と後期で比較検討すると，腎摘後進行 癌では後期の予後が前期より有意に良好であった。こ の理由としては，1）前期では病期診断が不十分で, 診 断時に既に進行癌であり診断時進行癌とするべきもの を腎摘後進行癌とし, 前期の腎摘後進行癌の予後を悪 くさせた可能性（前期の診断エラー），2）例衤ばIFN による新たな療法が後期では導入されており，そのた め腎摘後進行癌においての及予後が改善した可能性 (後期の治療法改善)，3）診断ェラーのない条件下で は，術後観察を頻繁に行らと転移が早期に発見され生 存率の起算日が早くなり結果的に生存期間が延長する が,この現象が後期に起こった可能性（後期の早期発 見）などが考えられる。

1)の点については, 図1に示したよらに, 前期の腎 摘後進行癌には腎摘後からの期間が極めて短い症例が 多数あった。これらの症例は診断時進行癌とされるべ きものであった可能性が高く，かつその予後はいずれ
も不良であった。このため前期の腎摘後進行癌の予後 が診断時進行癌の混入のため不良となった可能性は高 い.しかし, 後期での予後の改善は，2)の治療法改善 や3)の早期発見が寄与していた可能性も否定できな い. 例觉ば, 5 年以上の生存は前期で 2 例にすぎなかっ たが後期では 5 例にみられ，このことは診断ェラーだ けでは説明がつかない，そのいずれもが後期でより頻 用されているUFT やIFNを含む集学的治療を受け ていることも, 治療法の改善を裏付けるとも考えられ る. また腎摘後進行癌でのみ後期で予後の改善がみら れたといらことは, 進行癌のらちでも比較的治療しゃ すいもので有効な治療法が出現しつつあるとも言えよ 5.すなわち, 治療効果の改善が僅かの場合は, 進行 癌全体ではなくまず腎摘後進行癌の治療成績に反映さ れてくることが期待される。

以上より進行腎細胞癌の臨床的病像は前期之後期で 差はなく，また予後にも明らかな改善はなかったが, IFN やUFT などの薬剤を用いた集学的な併用療法に より，僅かながら治療効果が改善している可能性が示 唆された。

\section{結語}

1. 進行腎細胞癌について, その臨床的特徵の経時的 変遷について解析するために，1975年から1991年の 17 年間に当科及び分院で経験した 94 例を，前期の 48 例と 後期の 46例に分けその違いを検討した.

2. 進行癌の類型では遠隔転移を有する症例が $80 /$ 94 (85.7\%) とほとんどで，リンパ節転移のみあるい は局所の浸潤のみの症例は少なく，前期と後期では大 きな違いはなかった。

3. 診断時に既に進行癌である症例は, 前期と後期で その症例数には差はなく, 早期発見例が増えている一 方で診断時に既に進行癌である症例も依然として多い ことが示された。

4. 治療法については, 後期では IFN や5FU 系の薬 物が多用されていた一方で，放射線，他の抗癌剤や内 分泌療法はあまり用いられなくなっていた。また種々 の治療を総合した併用療法が試みられている例で長期 生存が観察された。

5. 全例での生存率は前期と後期では差を認めな かった。しかし腎摘後進行癌と診断時進行癌に分けて 前期と後期を比較すると, 腎摘後進行癌の久で後期は 前期にくらべて有意に予後が良好であった。

6. 進行腎細胞癌の病像と予後には前期と後期とで 明らかな変化はなかったが，予後の改善には外科的手 
術を含め, UFT IFN を用いた併用療法の重要性が 示唆された。

\section{文献}

1) Lang, E.K.: Comparison of dynamic and conventional computed tomography, angiography, and ultrasonography in the staging of renal cell carcinoma. Cancer, 54, 2205-2214, 1984.

2）本間之夫, 杉本雅幸, 䇾和田滋, 東原英二, 阿曽佳 郎：腎細胞癌124例の治療成績。日泌尿会誌, 81, 726-731, 1990.

3) Aso, Y. and Homma, Y.: A survey on incidental renal cell carcinoma in Japan. J. Urol., 147, 340-343, 1992.

4）本間之夫, 䇾和田滋, 東原英二, 阿曾佳郎：腎細胞 癌に対する $\alpha$ ーインターフェロンの治療経験. 日癌 治, 26, 755-759, 1991.

5) Skinner, D.G., Colbin, R.B., Vermillion, C.D., Pfister, R.C. and Leadbetter, W.F.: Diagnosis and management of renal cell carcinoma. Cancer, 28, 1165-1177, 1971.

6）里見佳昭：腎癌の治療の現況々今後の課題. 日泌 尿会誌，81，1-3，1990。

7) Quesada, J.R., Swanson, D.A., Trindade, A. and Gutterman, J.U.: Renal cell carcinoma : Antitumor effects of leukocyte interforone. Cancer Res., 43, 940-947, 1983.

8) Marumo, K., Murai, M., Hayakawa, M. and Tazaki, H. : Human lymphoblastoid interferone therapy for advanced renal cell carcinoma. Urol., 14, 567-571, 1985.

9）新島端夫，阿曾佳郎，赤座英之，亀山周二，小磯謙
吉, 河邊香月, 河村 毅, 岩動孝一郎, 横山正夫, 東海林文夫, 西村洋司, 三方律治, 木下健二, 浅野 美智雄, 中内浩二, 藤田公正, 小島弘敬, 落藤 博, 䇾和田滋, 石井泰憲, 斉藤 功, 书口照男, 岡田清 巳：UFT の進行腎細胞癌に対する臨床応用. 癌と 化学療法, 15, 109-114, 1988.

10) Bojar, H.: Hormone responsiveness of renal cancer. World J. Urol., 2, 92-98, 1984.

11）大西哲郎，増田富士男，仲田浄治郎，鈴木正泰，飯 塚典男, 町田豊平：腎細胞癌の放射線治療効果. 日 泌尿会誌，76，1154-1160，1985。

12) Feher, M., Pinter, J. and Szokoly, V.: Problems of the indications of radiotherapy in renal tumors after radical nephrectomy. Int. Urol. Nephrol., 16, 29-32, 1984.

13）山下雄二郎, 有吉朝美, 蓮尾研二, 白日高歩: 肺転 移を伴う腎癌の外科的治療成績. J. Jpn. Soc. Cancer Ther., 24, 759-764, 1989.

14）阿曾佳郎, 本間之夫：腎臓癌手術療法の現況. Karkinos, 11，65-74，1988.

15）藤目 真, 赤座英之, 吉田雅彦, 黒岡雄二, 谷口 淳, 岸 洋一, 梅田 隆, 岩動孝一郎, 新島端夫： 腎細胞癌の小脳転移. 日泌尿会誌; 77, 1164-1168, 1986.

16) Figlin, R.A., De-Kernion, J.B., Maldazys, J. and Sarna, G.: Treatment of renal cell carcinoma with $\alpha$ (Human Leukocyte) interferone and vinblastine in combination: A phase I-II trial. Cancer Treat. Rep., 69, 263-267, 1985. （1993年 3 月 5 日受付， 6 月 2 日受理） 